Int. J. Morphol.,

32(1):241-244, 2014.

\title{
The Liver Micromorphology of the African Palm Squirrel Epixerus ebii
}

\author{
Micromorfología del Hígado de la Ardilla de Palma Africana Epixerus ebii
}

Ikpegbu, E. ; Nlebedum, U. C.; Nnadozie, O. \& Agbakwuru, I. O.

IKPEGBU, E.; NLEBEDUM, U. C.; NNADOZIE, O. \& AGBAKWURU, I. O. The liver micromorphology of the African palm squirrel Epixerus ebii. Int. J. Morphol., 32(1):241-244, 2014.

SUMMARY: The normal liver histology of the African palm squirrel Epixerus ebii was investigated to fill the information gap on its micromorphology from available literature. The liver was covered by a capsule of dense connective tissue- the perivascular fibrous capsule. Beneath this capsule is the liver parenchyma were the hepatocyte were supported by reticular fibres. The hepatocytes in the lobules were hexagonal to polygonal in shape. Some hepatocytes were bi-nucleated. Clear spaces in the parenchyma must be storage sites for lipids in the liver. The classic hepatic lobules presented central vein surrounded by several liver cells. At the portal triad, hepatic vein, hepatic arteries and bile ducts were seen. While the hepatic arteries and veins were lined by endothelium, the bile ducts were lined by simple cuboidal cells. Nerve fibres were also seen in the region of the portal triad. Hepatic sinusoids lined by endothelium were seen in the liver parenchyma between liver lobules. The sinusoids contained macrophages. This report will aid wild life biologists in further investigative research and Veterinarians in diagnosing the hepatic diseases of the African palm squirrel.

KEY WORDS: Palm squirrel;Liver; Histology; Portal triad.

\section{INTRODUCTION}

The liver is the largest internal organ (Akiyoshi \& Inoue, 2004), containing as much as four to five lobes surrounded by capsule of connective tissue fibres referred to as perivascular fibrous capsule (Glissons capsule) (Petcoff et al., 2006). The liver parenchyma within the lobules is supported by fine reticular fibres. At the hilus, blood vessels, lymphatics and nerve enter and leave the liver. Within the parenchyma are sinusoids lined by macrophages called stellate macrophages (or Kupffer cells) (Lopez et al., 2011; Carollo et al., 2012). These sinusoids are usually in between the hepatic plates (Motta, 1984). The liver cells -hepatocytes are usually polygonal in shape and usually binucleated mamalian adults (Prunescu et al., 2002). The liver has both endocrine (protein secretion) and exocine (bile secretion) function. It also functions as a storage organ; synthesis of cholesterol, lipid portion of lipoprotein; metabolic activities like gyconeogenesis, deamination of amino acids, and detoxification of noxious substances (Akiyoshi $\&$ Inoue, 2004).
Rodents are the largest order in mammals. They are used as pets, laboratory animals and sources of animal protein (Nzalak et al., 2012). The squirrel being a rodent has wide geographical distribution, but the African palm squirrel is seen mostly in West Africa. From available literature, few studies have been conducted on the squirrel. These include reports on necrosy finding of nematodes on captive African squirrel (Craig et al., 1998), rabies in fox squirrel (Cappucci et al., 1972), hepatocellular carcinoma in Black-tailed prairie dogsCynomys ludivicionus (Garner et al., 2004), natural infection of the ground squirrel with Echinococcus granulosus (Yang et al., 2009). But in the African palm squirrel, there is dearth of information on its basic biology from available literature, hence this microanatomic investigation on its liver, one of the important mammalian organs. The result from this study will fill the knowledge gap. It will help wild life biologists in understanding its adaptive physiology and Veterinarians in managing hepatic diseases of the species.

* Department of Veterinary Anatomy, Michael Okpara University of Agriculture Umudike, Abia State, Nigeria. 


\section{MATERIAL AND METHOD}

Five adult African palm squirrels of both sexes captured in the wild from Olokoro Umuahia in Abia state, Nigeria from March to November 2012 using metal cage traps, were used for the study. Olokoro umuahia is in the rainforest vegetation of southern Nigeria characterized by heavy rains and thick well grown mangrove forest trees. They were immediately transferred to the veterinary anatomy laboratory of Michael Okpara University of Agriculture Umudike, for acclimatization. During this period, the animals were fed with grasses, oil palm fruit and water ad libitum.

The squirrel on the day of sacrifice was sedated with chloroform. The weight of the animal was taken with Mettler balance (Model Ohaus scout PRO-200) with a sensitivity of $0.1 \mathrm{gm}$. Each squirrel was euthanized by chloroform overdose and placed on dorsal recumbency. The animal was cut open through mid ventral incision from the inguinal region to the mandibular symphysis. The liver was dissected out and slices fixed in $10 \%$ neutral buffered formalin. The tissues were passed through graded ethanol, cleared in xylene, impregnated and embedded in paraffin wax. Sections $5 \mu \mathrm{m}$ thick were obtained with Leitz microtome model 1512. They were stained with haematoxylin and eosin for light microscopy examination. The slides were examined and photomicrographs taken with - Motican 2001 camera (Motican U.K.) attached to Olympus microscope.

\section{RESULTS}

Histologically, the liver was seen covered by a capsule composed of dense regular connective tissue fibres (Fig.1). the liver parenchyma contained hepatocytes- the liver cells in a cord like arrangement. These hepatocytes were polygonal in shape (Fig. 2). The liver lobule contained a central vein surrounded by hepatocytes (Fig. 2). Clear spaces were seen in the parenchyma between hepatocytes. The liver portal triad contained a hepatic vein, hepatic artery and bile ducts (Figs. 3 and 4). The hepatic vein lumen was wide and lined by simple squamous epithelium. The hepatic artery was was also lined by simple squamous epithelium, the smooth muscles of the tunica media were separated by the tunica intima by internal elastic laminar. The bile duct was lined by simple cuboidal cells (Fig. 4). Some nerve fibres were also at the portal triad (Fig. 4). Hepatic sinusoids were seen between liver lobules (Fig. 5). These sinusoids were lined by discontinuous endothelium and macrophages were seen at the sub-sinusoidal space (Fig. 5).

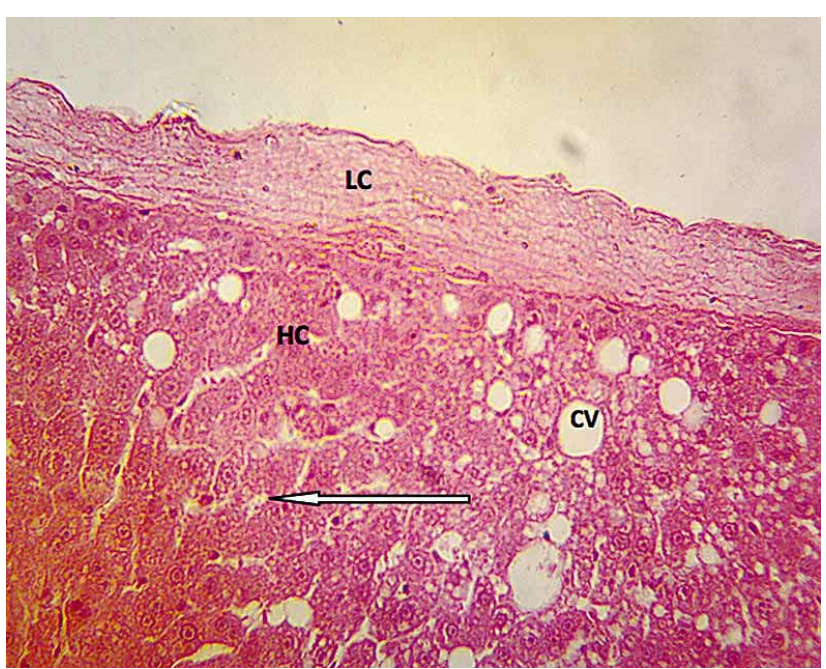

Fig. 1. Section of the liver region showing mucus cells MC, liver capsule LC, hepatocytes HC, clear lipid spaces (white arrow), and central vein $C V$. $H \& E$ x 400

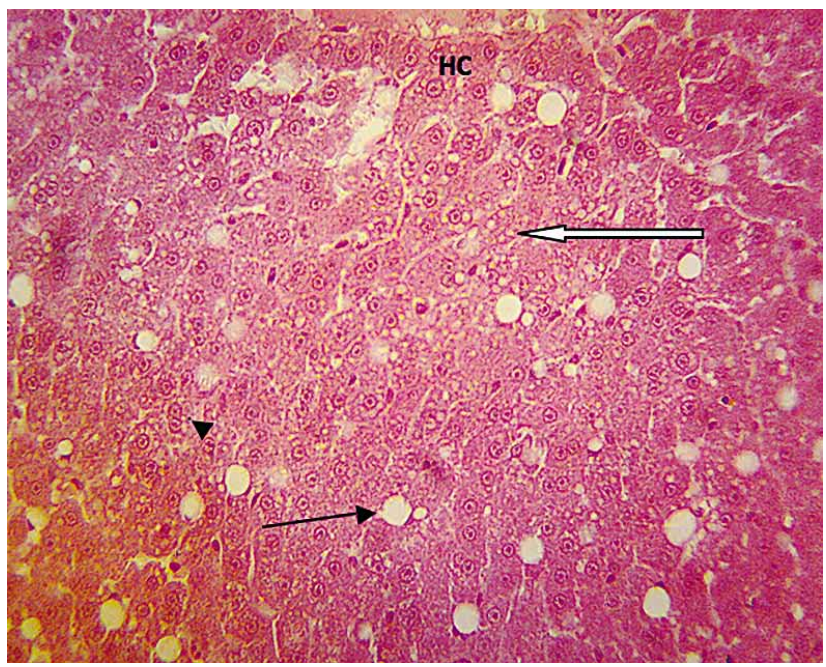

Fig. 2. Section of the liver parenchyma showing polygonal hepatocytes HC, central vein (black arrow), and clear lipid spaces (white arrow). Note the binucleated hepatocytes (black arrow head). $\mathrm{H} \& \mathrm{E} \mathrm{x} 400$.

\section{DISCUSSION}

The result of this study shows that the Palm squirrel liver histology is similar to most other mammals. The perivascular fibrous capsule is for protection of the liver parenchyma. The dense regular connective tissue fibers seen in this liver has been reported in the adult European bison, Bison bonasus containing arteries and lymphatics (Prunescu et al.). The hepatocytes of polygonal shape is the liver cell reponsible for its physiologic functions (Ayikoshi \& Inoue, 2012). The binucleated hepatocytes observed in this study has also been repoterd (Prunescu et al.). A classic hepatic 


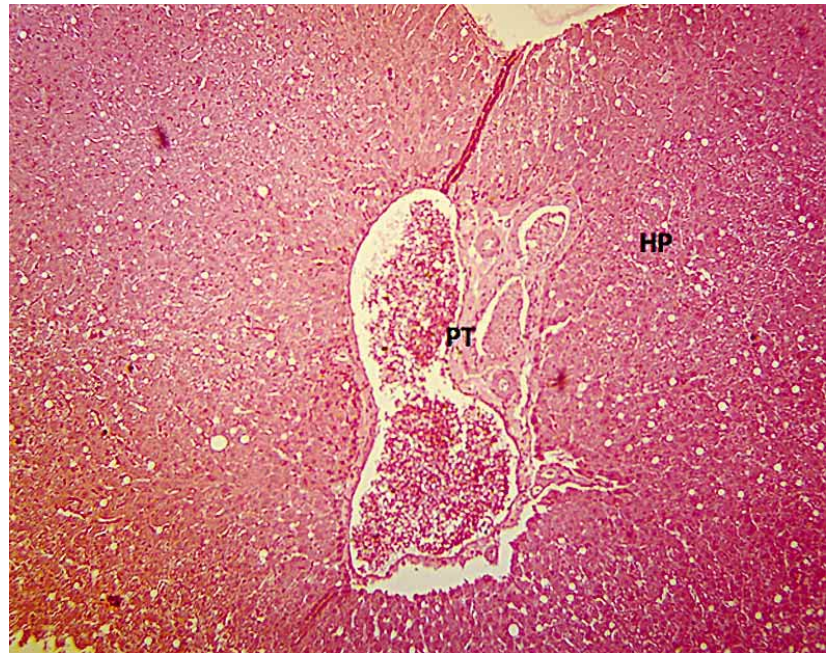

Fig. 3. Section of the liver showing hepatic parenchyma PC, portal triad PT, containing hepatic artery and vein, and bile duct. H\&E $\mathrm{x} 400$

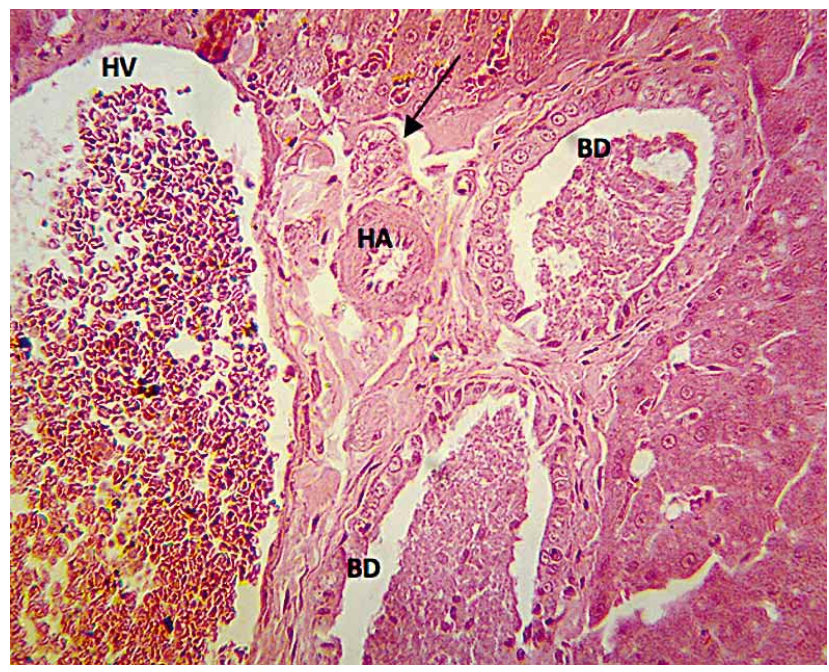

Fig. 4. Section of the liver showing hepatic portal triad PT, containing hepatic artery HA, hepatic vein $\mathrm{HV}$, and bile duct BD. Note nerve fiber (black arrow) in the portal triad area. H\&E x400.

lobule with a central vein has also been reported (Ayikoshi \& Inoue, 2012), and is the liver's basic functional unit. The clear empty spaces seen in the liver parenchyma inbetween the hepatocytes may be the extracellular lipid storage sites in the liver, but more work should be done to acertain this claim. The sinusoids present is for free exchange of materials between the hepatocytes and the vascular system.

The macrophages present in the perisinusoidal space is for local defence through phagocytosis of pathogens (Parker \& Picut, 2005; Carollo et al.). These macrophages refered to as stellate macrophages (Kupffer cells) have also been reported in other mammals (Carollo et al.). The portal triad of hepatic vein, hepatic artery and bile ducts has been

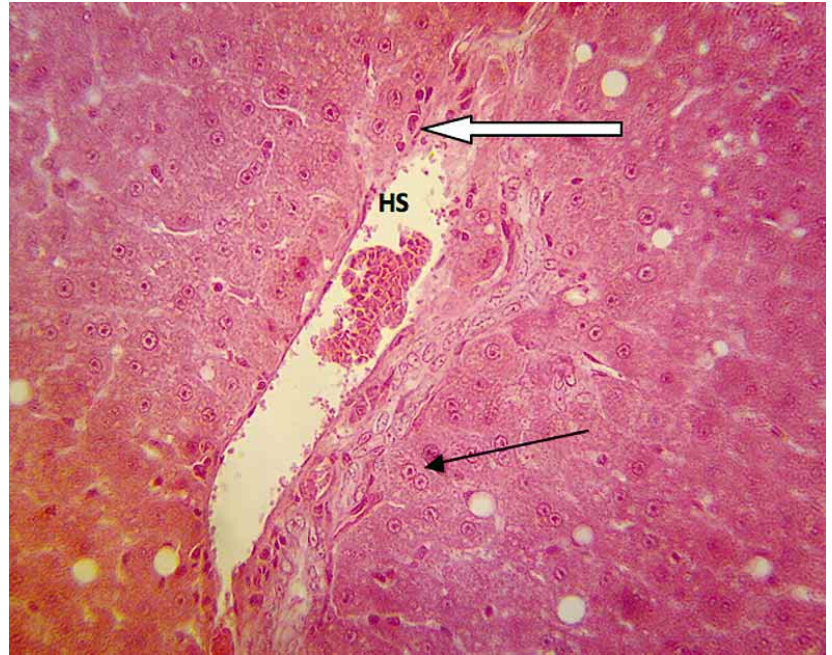

Fig. 5. Section of the liver showing hepatic sinusoid HS, subsinusoidal macrophages (white arrow). Note the binucleated hepatocytes (black arrow). H\&E x400.

reported in literature (Motta; Parker \& Picut). The prominent bile duct maybe an adaptation for easy passage of bile salts from the liver to the duodenum since a gall bladder is absent in some rodents as also seen in this study (Voss, 1991). The absence of lymphatics at the portal area suggest that lymphatics are not regular feature of squirrel portal triad, hence it is not a tetrad as reported in some mammals. The presence of nerve fibres in the portal area is unique as it has not been reported in other rodents from available literature.

IKPEGBU, E.; NLEBEDUM, U. C.; NNADOZIE, O. \& AGBAKWURU, I. O. Micromorfología del hígado de la ardilla de palma africana Epixerus ebii. Int. J. Morphol., 32(1):241-244, 2014.

RESUMEN: Describimos la histología hepática normal de la ardilla de palma africana Epixerus ebii para llenar el vacío sobre su micromorfología en la literatura disponible. El hígado está cubierto por una cápsula de tejido conectivo denso, la cápsula fibrosa perivascular. Debajo de esta cápsula se encuentra el parénquima hepático en el cual fibras reticulares apoyan los hepatocitos. Los hepatocitos en los lóbulos son hexagonales de forma poligonal. Observamos algunos hepatocitos bi-nucleados. Evidentes espacios en el parénquima deben ser emplazamientos de almacenamiento de los lípidos en el hígado. Los lóbulos hepáticos clásicos presentan una vena central rodeada de varias células hepáticas. En la tríada portal, se observó la vena hepática, las arterias hepáticas y los conductos biliares, mientras que las arterias y venas hepáticas estaban revestidas por endotelio, los conductos biliares estaban alineados por células cuboides simples. También se observaron fibras nerviosas en la región de la tríada portal. Sinusoides hepáticos revestidos por endotelio fueron observados entre los lobulillos hepáticos en el parénquima hepático. Los 
sinusoides contenían macrófagos. El presente estudio ayudará a los biólogos de la fauna silvestre en una investigación más precisa, y a los médicos veterinarios en el diagnóstico de las enfermedades hepáticas en la ardilla de palma africana.

PAlabras ClaVE: Ardilla de Palma; Hígado; Histología; Tríada portal.

\section{REFERENCES}

Akiyoshi, H. \& Inoue, A. Comparative Histological Study of Teleost Livers in Relation to Phylogeny. Zoolog. Sci., 21(8):841-50, 2004.

Akiyoshi, H. \& Inoue, A. M. Comparative histological study of hepatic architecture in the three orders amphibian livers. Comp. Hepatol., 11(1):2, 2012.

Cappucci, D. T. Jr.; Emmons, R. W. \& Sampson, W. W. Rabies in an eastern fox squirrel. J. Wildl. Dis., 8(4):340-2, 1972.

Carollo, V.; Giancamillo, D. A.; Vitari, F.; Schneider, R. \& Domeneghini, C. Immunohistochemical Aspects of Ito and Kupffer Cells in the Liver of Domesticated and Wild Ruminants. Open J. Vet. Sci., 2(3):129-36, 2012.

Craig, L. E.; Kinsella, J. M.; Lodwick, L. J.; Cranfield, M. R. \& Strandberg, J. D. Gongylonema macrogubernaculum in captive African squirrels (Funisciurus substriatus and Xerus erythropus) and lion-tailed macaques (Macaca silenus). J. Zoo. Wildl. Med., 29(3):331-7, 1998.

Garner, M. M.; Raymond, J. T.; Toshkov, I. \& Ennant, B. C. Hepatocellular Carcinoma in Black-tailed Prairie Dogs (Cynomys ludivicianus): Tumor Morphology and Immunohistochemistry for Hepadnavirus Core and Surface Antigens. Vet. Pathol., 41(4):353-61, 2004.

Lopez, B. G.; Tsai, M. S.; Baratta, L. J.; Longmui, K. J. \& Robertson, R. T. Characterization of Kupffer cells in livers of developing mice. Comp. Hepatol., 10(1):2, 2011.

Motta, P. M. The three-dimensional microanatomy of the liver. Arch. Histol. Jpn., 47(1):1-30, 1984.

Nzalak, J. O.; Onyeanusi, B.I.; Salami, S.O. Macrometric study of the digestive system of the African giant rat (Cricetomys gambianus, Waterhouse 1840). Eur. J. Anat., 16(2):113-8, 2012.

Parker, G. A. \& Picut, C. A. Liver Immunobiology. Toxicol. Pathol., 33(1):52-62, 2005.

Petcoff, G. M.; Díaz, A. O.; Escalante, A. H. \& Goldemberg, A. L. Histology of the liver of Oligosarcus jenynsii (Ostariophysi,
Characidae) from Los Padres Lake, Argentina. Iheringia, Sér. Zool., 96(2):205-8, 2006.

Prunescu, C.; Prunescu, P.; Krasinska, M. \& Krasinski, Z. A. Liver histological structure in adult European bison. Bison bonasus (Linnaeus, 1758). Folia Morphol. (Warz), 61(3):137-42, 2002.

Voss, R. S. An introduction to the Neotrpoical muroid rodent genus Zygodont-amys. Bull. Am. Mus. Nat. Hist., 210:1-113, 1991.

Yang, Y. R.; Liu, T.; Bai, X.; Boufana, B.; Craig P. S.; Nakao, M.; Ito, A.; Zhang, J. Z.; Giraudoux, P. \& McManus, D. P. Natural Infection of the Ground Squirrel (Spermophilus spp.) with Echinococcus granulosus in China. PLoS Negl. Trop. Dis., 3(9):e518, 2009.

\author{
Correspondence to: \\ Ekele Ikpegbu \\ Department of Veterinary Anatomy \\ Michael Okpara University of Agriculture Umudike \\ Abia State \\ NIGERIA
}

Email: fikpegbu@yahoo.com

Received: 30-05-2013

Accepted: 16-12-2013 